\title{
Implementation Policy of The Arrangement and Formation of Modern Shop that Requires for Partnerships with Small and Medium Micro Enterprises (UMKM) Based on Perda No.12 of 2017 in Kudus Regency
}

\begin{abstract}
Atik Noer Chalimah ${ }^{1}$
Abstract. This research was made based on the Government Regulations of the Kudus Regency issuing Regional Regulation No. 12 of 2017 concerning Modern Store Arrangement and Guidance roomates requires Modern Stores to establish partnerships with the Small and Medium Micro Enterprises (UMKM), as well as discussing the operational hours items, namely the people of Kudus Regency who have implemented a a policy of obligation to establish partnerships between Several modern stores Small and Micro Businesses and intermediate so that in this thesis to find out the factors that Become obstacles and how the District Government's Strategic Efforts in developing Small and Medium Micro Enterprises. This research uses descriptive type or types of research. Descriptive research is a type of research that describes the findings of variables in the field that do not require a hypothesis scale. So its nature only illustrates and describes the findings in the field. The results of this study are based on interviews with the District Office of the Kudus Industry, the Department of Trade in the District of Kudus, and the empowerment of Micro Small and Medium Enterprises.

Keywords: Implementation; Empowerment of Micro Small and Medium Enterprises; Public Policy; Modern Stores.
\end{abstract}

\section{Introduction}

In the midst of economic social problems of Indonesian society and the demands of the economic wellbeing of late. Not only economic factors that influence in the field of trade or business but there is also the political, legal, social and technology also play an important role in economic development, including one of the developments in the economy is the development of shopping centers and modern stores in Indonesia grew rapidly over time, One of them in the Kudus city, rise of modern retail is growing rapidly in urban and rural areas, where modern stores provide positive and negative effects and also existence disturbing local residents, especially the small traders or traditional retail minimal infrastructure, the advantages of modern retail they provide the required In addition, the amount of goods that much, neat arrangement of items and lots of promo or discount in price every month, and there are special prices of customers or members. not infrequently encountered goods limited which is not found in traditional retail, in contrast to the traditional retail they do not give a discount or special pricing members, it makes consumers prefer modern retail than traditional retail although modern retail prices are more expensive.

Worldwide legal function of regulating and restricting - economic activities in the hope of economic development does not waive rights - the rights and interests of the

\footnotetext{
${ }^{1}$ Student Masters (S-2) of Law Faculty of Law UNISSULA Semarang E-mail: atikhazan@yahoo.co.id
} 
community. ${ }^{2}$ Regarding the fate of small traders or traditional merchant was and is actually not much different. Every day they have to collect the rupiah for rupiah to cover the needs of daily life and raise capital to buy goods for resale. However, being a trader in the past, perhaps more profitable in comparison in the present. ${ }^{3}$

Simon Kuznets define economic growth as a long-term increase in the ability of the State to provide more and more kinds of economic goods to its citizens, this ability to grow in accordance with advances in technology, and adjustment of institutional and ideological. ${ }^{4}$

Finally in 2017 the Kudus district government issued a Local Regulation No. 12 Of 2017 concerning Management and Development of the modern shop Modern shop requires partnerships with UMKM, As well as considerations about the operating hours. Background issued Local Regulation 12 Of 2017 concerning Management and Development of the modern shop, which requires modern store partnerships basically is with the development of retail trade in small and medium scale, retail trade of modern on a large scale, as well as the need to empower economic actors in order to grow and develop in harmony, mutual need, mutual strengthening and mutual benefit so as not to cause economic jealousy. Explanation on Article 14, which regulates the partnership. In Article 14 Paragraph (1), states that any person or entity that will conduct business modern stores are required to conduct partnerships with UMKM (small and medium micro). Among the forms of partnership cooperation in the form of marketing, provision of business location, or the provision of supplies. Partnerships can be implemented with the principle of mutual benefit, clear, fair, equitable, and transparent. UMKM (Micro, Small and Medium Enterprise) that there will be chosen who does have a strong desire to follow the desired quality standards of the modern shop. Even if not in accordance with the standards, there is hope of modern stores are willing to provide guidance and feedback so that products can be according to the standard.

Business Competition Supervisory Commission (KPPU) to supervise the implementation of the partnership between big business with UMKM. Supervision is done in coordination with relevant agencies. The Commission also authorized to impose administrative sanctions on businesses large or medium businesses who commits an offense, which is detrimental to the ownership or control of UMKM business in a partnership. ${ }^{5}$

Top notch franchise partnership in the partnership scheme, great effort serves as franchisor, while UMKM serves as franchisees. Or medium-sized businesses as a franchisor based on micro- and small enterprises. This could be a good example for other cities if the results of these policies could give a positive result to advance the welfare of the people especially the Kudus district and not cause economic inequality. In the economic development in Indonesia is always portrayed as a sector UMKM with an important role, because most of the population is poorly educated and live in small

\footnotetext{
2 Sari,Elsa Kartika 2005 Hukum Dan Ekonomi PT. Grasindo Jakarta p. 4.

${ }^{3}$ Herman Malano 2011 Selamatkan Pasar Tradisional Gramedia Pustaka Utama Jakarta p. 19.

${ }^{4}$ M.L. Jhingan 2012 Ekonomi Pembangunan Dan Perencanaan PT. Raja Grafindo Persada Jakarta p. 57.

${ }^{5}$ Presidential Regulation (PP) No. 17 of 2013 on Implementation Act No.20 of 2008
} 
business activity in both traditional and modern sectors. ${ }^{6}$ This makes the development of UMKM one of the activities carried out by the government in improving the economy. Development of Micro, Small and Medium Enterprises (UMKM) is essentially a shared responsibility between the government and the public. ${ }^{7}$

In Government Regulation No. 17 of 2013 on the implementation of Act No. 20 of 2008 on Micro, Small and Medium Enterprises stated that the development effort is made to Micro, small and medium-sized businesses. Business development may include the facilitation and implementation of business development. National and regional governments to prioritize the development of Micro, small and medium enterprises in various ways. $^{8}$

Should this partnership is a cooperation of mutual benefit both parties either store modern and UMKM, facts that occurred sometimes there is also the modern stores that do not provide a place or a display case and also the payment is not smooth, and often the modern store is only receiving food long dry expiry another with wet food, the weakness of the UMKM sometimes they are unable to meet the targets of the modern shop orders in because of limited capital.

Based on the above description of the background authors conducted a study with the title of Kudus District Government Policy Implementation in local rules of the Kudus District No. 12 of 2017 on Management and Development of modern shops, which requires partnering with small and medium micro enterprises?

\section{Research methods}

This study uses the type or types of descriptive research. Descriptive research is a type of research that describes the findings of the variable in the field that do not require the hypothesis scale. So it is only illustrate and describe the findings in the field.

\section{Results And Discussion}

Kudus District Government's efforts in the development of micro, small and medium enterprises $^{9}$

- Processing production field by providing convenience in the provision of infrastructures of production, processing and packaging for products of UMKM and

\footnotetext{
${ }^{6}$ Pradnya Paramita Hapsari Abdul Hakim Saleh Soeaidy. 2014. Pengaruh Pertumbuhan Usaha Kecil Menengah (UKM) terhadap Pertumbuhan Ekonomi Daerah (Studi di Pemerintah Kota Batu). Jurnal Wacana-Vol. 17 No. 2. Public Administration Faculty of Administration University of Brawijaya.

${ }^{7}$ Mohammad Jafar Hafsah. 2004. Upaya Pengembangan Usaha Kecil dan Menengah (UKM) Infokop No. $25 \mathrm{XX}$.

${ }^{8}$ According to the PP 17 In 2013 there are several ways to empower SMEs are:

a. Providing the opportunity to participate in preparing Gomerment's goods and services of the Regional Government;

b. Backup business for Micro Small and Medium Enterprises

c. Ease of licensing

d. Financing role the regualation provision in accordance with the laws; or

e. Facilitation of technology and information.

${ }^{9}$ Accessed from the website: http://www.kuduskab.go.id/p/133/umkm taken on 10 September 2018 at 19:00
} 
managerial capabilities through the help of the means of production and micro loans.

- Marketing field which provides facilities which includes trading houses, and the promotion of micro and small enterprises through support for product promotion and marketing network funding UMKM exhibition (Small and Medium Enterprises and Cooperatives / Agencies Marketing Services Cooperatives and Small and Medium Enterprises),

- The field of human resource development is to promote and cultivate entrepreneurship through socialization legislation on UMKM, carrying out training, counseling, motivation and the creation of new entrepreneurs through entrepreneurship technical guidance, counseling, licensing regulations and the creation of new entrepreneurs.

- The field of design and technology in the form of increased cooperation and transfer of technology through the establishment of industrial centers, associations, association, joint venture group, comparative study, encourage UMKM to obtain Intellectual Property Rights through counseling and financial assistance to acquire the intellectual property rights of copyright.

UMKM development include the provision of facilities guidance counseling or traning in the sanctuary there is a program of training centers (BLK) and help strengthening the financing of both the provision of funds by government financial institutions banks and institutional financing non-banks to strengthen capital and loan guarantee business by the Institute of Credit Guarantee, as a support to increase the chances of getting the loan.

To realize the development of the national economy based on economic democracy, the micro small and medium enterprises need to be empowered as part of the economy. Empowerment is done through the provision of business opportunities, support, protection and development of the broadest effort so that UMKM can grow and become independent businesses.

The purpose of empowering the MUMKM:

- Realize balanced economic structure, developing and justice

- UMKM to grow and develop capabilities into a strong and independent business

- Enhancing the role of UMKM in regional development, job creation, income generation, economic growth and the alleviation of people out of poverty criteria:

- Micro, which has a net worth max Rp 50 million (excluding land and buildings) has annual sales of USD 300 million max.

- Small businesses have a net worth max USD 500 million (excluding land and buildings) has annual sales of USD 2.5 billion max

- Medium Enterprises have a net worth max Rp 10 billion (excluding land and buildings) has annual sales of USD 50 billion max.

Examples of products of UMKM is marketed in the modern store in the Kudus City There Mall:

- Fried "Wader".

- Herbal Drinking "Kelenceng".

- Stick Flavor Fish

- "Mongso" Honey 
- Salted Eggs

- Mr. "Bandeng" etc.

The partnership cooperation would benefit both sides, they take profit about $20-25 \%$ of the price of the product, the seller is a variety of systems ranging cooperation, outright to sell Barriers experienced entrusted UMKM include: Legality, Wet Products, Capital, and Lack of supply of goods. So far, the new modern stores accept food and beverage requirements to be standart sale is legality, packaging and "halal haram" product is not a top priority.

According to Mr. Ganda Saragih as manpower Representatives of industry, cooperatives and UMKM are the most important thing in managing UMKM need is motivation and willingness themselves to be entrepreneurs, because there are already many services capital in banks and nonbank institutions.

\section{Closing}

\subsection{Conclusion}

Based on the results of research and discussion concluded:

- Kudus District Government's efforts in the development of micro, small and medium enterprises through the fields of marketing, production, development and design field

- Obstacles encountered in the development of UMKM in particular are forming partnerships with modern store is the capital, supplies which do not meet the request and payment of the arrears modern shops.

\subsection{Suggestion}

- The results of this study are expected to add insight to the economic development of Micro, Small and Medium Enterprises.

- For the manager of Micro, Small and Medium Enterprises can be made in reference to overcome the obstacles encountered in management businesses, particularly capital constraints.

- Can be used as a benchmark for the evaluation and development of small and medium.

\section{Bibliography}

[1] M.L. Jhingan 2012 Ekonomi Pembangunan Dan Perencanaan PT. Raja Grafindo Persada Jakarta.

[2] Herman Malano 2011 Selamatkan Pasar Tradisional Gramedia Pustaka Utama Jakarta.

[3] Sari Elsa Kartika 2005 Hukum Dan Ekonomi PT. Grasindo Jakarta.

[4] Pradnya Paramita Hapsari Abdul Hakim Saleh Soeaidy 2014 Pengaruh Pertumbuhan Usaha Kecil Menengah (UKM) terhadap Pertumbuhan Ekonomi Daerah (Studi di Pemerintah Kota Batu) Jurnal Wacana-Vol. 17 No. 2. Public Administrasion Faculty of Administrasion University of Brawijaya 
[5] Mohammad Jafar Hafsah 2004 Upaya Pengembangan Usaha Kecil dan Menengah (UKM). Infokop No. 25 of XX.

[6] President Regulation (PP) No.17 of 2013 on implementation of Act No.20 of 2008

[7] Accessed from the website: http://www.kuduskab.go.id/p/133/umkm taken on 10 September 2018 at 19:00 